\title{
OBOWIAZZKI ADMINISTRACJI OBRONY NARODOWEJ W ZAKRESIE OCHRONY ŚRODOWISKA
}

\begin{abstract}
Środowisko naturalne stanowi wartość o charakterze powszechnym. Każda jednostka w państwie ma prawo korzystać swobodnie ze środowiska naturalnego, jednak, aby zachować jego pożądany stan istnieją pewne ograniczenia związane z jego korzystaniem oraz obowiązki, które społeczeństwo musi realizować w celu utrzymania środowiska w należytym stanie. Ochrona środowiska w istocie sprowadza się do podejmowania działań lub zaniechań, które umożliwiają zachowanie lub przywrócenie równowagi przyrodniczej. Chodzi w tym przypadku o to, aby kształtować środowisko w sposób racjonalny, jak też by gospodarować jego zasobami zgodnie z zasadą zrównoważonego rozwoju, przeciwdziałając zanieczyszczeniom, czy też przywracając elementy przyrodnicze do stanu właścicielskiego. Ochrona środowiska jest zatem jednym $\mathrm{z}$ głównych zadań państwa, toteż w związku z postępem cywilizacyjnym, coraz więcej aktywności w tym zakresie przypisuje się różnym podmiotom administracji publicznej, w tym także pewna sfera zadań w tym zakresie została powierzona działowi administracji rządowej - obrona narodowa. Administracja publiczna bowiem wyposażona została w liczne instrumenty i narzędzia prawne, które umożliwiają jej zabezpieczanie środowiska naturalnego przed czynnikami mogącymi w sposób niekorzystny wpływać na jego degradację. Natomiast obowiązujące w tej sferze powszechne regulacje normatywne stanowią przykład pożądanych rozwiązań ukierunkowanych na zapobieganie zagrożeniom dla środowiska naturalnego. Prezentowany artykuł ma zatem na celu ukazanie problematyki ochrony środowiska w aspekcie obowiązków, jakie ma do zrealizowania w tym zakresie administracja obrony narodowej.
\end{abstract}

Słowa kluczowe: bezpieczeństwo, środowisko, administracja, obrona narodowa.

\section{ZASADA ZRÓWNOWAŻONEGO ROZWOJU}

Dynamiczny rozwój współczesnej cywilizacji obok licznych korzyści niesie ze sobą także wiele zagrożeń dla środowiska naturalnego. Ustawodawca chcąc zapewnić równowagę pomiędzy osiągnięciami cywilizacyjnymi a ich negatywnym wpływem na środowisko naturalne określił istotę zrównoważonego rozwoju - konstytucyjną zasadę odnoszącą się do omawianej problematyki.

We współczesnym bowiem prawie ochrony środowiska zasada zrównoważonego rozwoju pełni rolę swoistego rdzenia, wokół którego koncentrują się regulacje szczegółowe. Wywodzi się ona z międzynarodowego prawa ochrony środowiska, zaś pierwszy raz w ustawodawstwie krajowym została wyrażona w art. 5 Konstytucji Rzeczypospolitej

\footnotetext{
${ }^{1}$ Dr Oktawia Jurgilewicz, adiunkt w Katedrze Prawa i Administracji, Wydział Zarządzania, Politechnika Rzeszowska im. Ignacego Łukasiewicza, Al. Powstańców Warszawy 6, 35-959 Rzeszów; e-mail: niemieco@prz.edu.pl.
} 
Polskiej z dnia 2 kwietnia 1997 r. ${ }^{2}$ w brzmieniu, że Polska ma obowiązek strzec niepodległości i nienaruszalności swojego terytorium, zapewniać wolności i prawa człowieka i obywatela oraz bezpieczeństwo obywateli, jak również strzec dziedzictwo narodowe oraz zapewniać ochronę środowiska, kierując się zasadą zrównoważonego rozwoju.

W zaprezentowanej treści ustawodawca określił zasadnicze kierunki i cele działania państwa. Kluczową z nich jest niewątpliwie obowiązek ochrony niepodległości oraz nienaruszalności terytorium RP (za co odpowiedzialna jest przede wszystkim administracja obrony narodowej), gdyż skuteczność w tym zakresie pozwala na wykonywanie pozostałych funkcji o charakterze wewnętrznym, jak m.in. zapewnienie wolności i praw człowieka i obywatela, bezpieczeństwa, ochrony dziedzictwa narodowego, ale też - co warto podkreślić - ochrony środowiska. U podstaw realizacji tych funkcji leży zasada zrównoważonego rozwoju państwa i gospodarki narodowej3 ${ }^{3}$.

Usytuowanie zaś problematyki związanej z ochroną środowiska już na wstępie ustawy zasadniczej stanowi o jej wyjątkowym charakterze. Ustawodawca konstytucyjny formułując dany zapis po raz pierwszy na tym szczeblu źródeł wewnętrznego prawa zwrócił uwagę na jej doniosły charakter zwracając uwagę na wyjątkowy charakter środowiska naturalnego, w którym egzystuje człowiek.

Rozpatrując istotę zasady zrównoważonego rozwoju w systemie polskiego prawa, należałoby zastanowić się, kto jest jej adresatem oraz kto ma wykonywać obowiązki wynikające z tej zasady. Wykładnia językowa bowiem prowadzi do wniosku, iż obowiązki w zakresie realizacji tej zasady leżą po stronie RP, czyli są one nałożone na władze publiczne, a zwłaszcza na organy stanowiące oraz stosujące prawo powszechnie obowiązujące. Poza tym należ zwrócić także uwagę, że do urealnienia zasady zrównoważonego rozwoju obowiązany jest przede wszystkim ustawodawca. W procesie bowiem stanowienia prawa powinien nie tylko powoływać się na tę zasadę, ale też recypować do systemu polskiego prawa szczegółowe obowiązki z niej wynikające. W drugiej zaś kolejności zasadę tę powinny mieć na uwadze organy stosujące prawo. Niekiedy bowiem stan faktyczny wymaga rozważenia i wyważenia rozwiązań korzystniejszych - dylemat ten, organ stosujący prawo, może rozwiązać z wykorzystaniem zasady zrównoważonego rozwoju. Jednakże ograniczanie zakresu stosowania tej zasady jedynie do władzy publicznej jest zdecydowanym uproszczeniem. Zasada ta bowiem zawiera w sobie treści, które nakładają obowiązki także na inne podmioty. Brak aktywnego uczestnictwa w realizacji tej zasady ze strony innych podmiotów niż władze publiczne uczyniłby ją zaś trudną w realizacji.

Ponadto zasada zrównoważonego rozwoju dotyczy również praw i wolności jednostki, a zatem ma bezpośrednie przełożenie na ich sytuację prawną. Zrównoważony rozwój należy postrzegać nie tyle $\mathrm{w}$ odniesieniu do każdego człowieka indywidualnie, ile do ludzkości jako takiej, obejmującej zarówno obecne, jak i przyszłe pokolenia. Zasada zrównoważonego rozwoju ma więc wymiar ogólnoludzki, a nie indywidualny ${ }^{4} \mathrm{i}$ winna być stosowana przez każdego obywatela.

2 Dz.U. z 1997 r., nr 78, poz. 483 ze zm. (dalej jako: Konstytucja RP).

3 W. Skrzydło, Konstytucja Rzeczypospolitej Polskiej, Komentarz, wyd. VII, lex online (dostęp: 09.05.2017 r.).

${ }^{4}$ B. Rakoczy, Komentarz do Konstytucji Rzeczypospolitej Polskiej [w:] Prawo ochrony środowiska. Komentarz, lex online (09.05.2017 r.). 


\section{ZNACZENIE PODSTAWOWYCH POJĘĆ}

Rozpatrując problematykę ochrony środowiska warto ukazać znaczenie kilku pojęć, pośród których szczególne znaczenie ma bezpieczeństwo. Powszechne znaczenie tego terminu występuje niemal we wszystkich dziedzinach życia i oznacza brak zagrożeń, jak również poczucie pewności stanowiące naczelną potrzebę człowieka i grup społecznych ${ }^{5}$.

Szersza definicja tego pojęcia nakazująca uwzględniać potrzeby człowieka oznacza stan dający poczucie pewności oraz gwarancję jego zachowania wraz z szansą na ciągłe doskonalenie. W takim wymiarze bezpieczeństwo oznacza jedną z podstawowych potrzeb człowieka, ale też sytuację charakteryzującą się brakiem ryzyka utraty czegoś, co człowiek szczególnie ceni np.: życie, zdrowie, pracę, dobra materialne itp. ${ }^{6}$.

Bezpieczeństwo zatem dotyczy wszystkich, występuje na różnych płaszczyznach życia i obejmuje zabezpieczenie różnych potrzeb: istnienia, pewności, przetrwania, stabilności, tożsamości, niezależności, ochrony poziomu oraz jakości życia?

Warto także zaznaczyć, że bezpieczeństwo będąc jedną z nadrzędnych potrzeb każdej jednostki, jak również określonym stanem świadomości lub psychiki podmiotu pozwala ukazać różne stany związane z jego zagrożeniem. Będą to m.in.: stan braku bezpieczeństwa - występuje, gdy istnieje duże rzeczywiste zagrożenie, a przestrzeganie tego zagrożenia jest prawidłowe; stan obsesji - występuje, gdy nieznaczne zagrożenie postrzegane jest jako duże; stan fałszywego bezpieczeństwa - występuje, gdy zagrożenie jest poważne a postrzegane jest jako niewielkie; czy też stan bezpieczeństwa, które występuje, gdy zagrożenie zewnętrzne jest nieznaczne, a jego postrzeganie prawidłowe ${ }^{8}$.

W literaturze przedmiotu zjawisko bezpieczeństwa jest klasyfikowane według różnych kryteriów. Najbardziej popularnym podziałem bezpieczeństwa jest:

- bezpieczeństwo podmiotowe: bezpieczeństwo narodowe i bezpieczeństwo międzynarodowe;

- bezpieczeństwo przedmiotowe: bezpieczeństwo polityczne, wojskowe, społeczne, kulturowe, ideologiczne, informacyjne, ekologiczne;

- bezpieczeństwo przestrzenne: bezpieczeństwo lokalne, regionalne i globalne9.

Jak sygnalizowano, jednym z rodzajów bezpieczeństwa jest bezpieczeństwo ekologiczne, które można zdefiniować jako stan, który zostaje uzyskany na skutek uwzględnienia licznych uwarunkowań chroniących człowieka i środowisko oraz takiego ukształtowania stosunków naturalnych i społecznych w biosferze Ziemi, które tworzą właściwe warunki życia dla całej ludzkości, nie podważając zarazem podstaw życia na naszej planecie, głównie poprzez wdrożenie i realizację koncepcji zrównoważonego rozwoju ${ }^{10}$.

Źródłem zatem powstania zagrożeń ekologicznych jest działalność ludzka, która może w efekcie doprowadzić ludzkość do unicestwienia. Załamanie równowagi przyrodniczej, jako następstwo nadmiernej eksploatacji zasobów środowiska, zanieczyszczenie sfer ziemi i otoczenia przez substancje pochodzenia przemysłowego, transportowego oraz komu-

5 M. Jurgilewicz, Bezpieczeństwo zgromadzeń. Komentarz praktyczny, Warszawa 2015, s. 17.

6 J. Kaczmarek, W. Łepkowski, B. Zdrodowski (red.), Stownik terminów z zakresu bezpieczeństwa narodowego, Warszawa 2008, s. 14.

7 E. Nowak, M. Nowak, Zarys teorii bezpieczeństwa narodowego, Warszawa 2011, s. 13.

8 J. Stańczyk, Wspótczesne pojmowanie bezpieczeństwa, Warszawa 1996, s. 17.

9 J. Kaczmarek, W. Łepkowski, B. Zdrodowski (red.), Stownik terminów..., s. 15. Por. M. Jurgilewicz, Bezpieczeństwo..., s. 17-18.

${ }^{10}$ Ibidem, s. 142. 
nalnego, postępująca degradacja ekosystemów na skutek zanieczyszczeń odpadami toksycznymi oraz katastrofy ekologiczne to najczęstsze źródła ww. zagrożeń ${ }^{11}$.

Natomiast stosując kryterium przedmiotowe do zagrożeń ekologicznych należy zaliczyć: zagrożenia o charakterze naturalnym (powodowane są one działaniami sił przyrody), do których należy zaliczyć m.in.: powodzie, susze, huragany, trąby powietrzne, silne mrozy, wybuchy wulkanów, rozwój pasożytów jak też przestrzenne pożary lasów, jak również zagrożenia o charakterze antropogenicznym takie jak m.in.: awarie, katastrofy chemiczne i jądrowe, długotrwałe emisje szkodliwych dla organizmów substancji, czy też zanieczyszczenia odpadami.

\section{OCHRONA ŚRODOWISKA JAKO ELEMENT BEZPIECZEŃSTWA EKOLOGICZNEGO W ŚWIETLE POSTANOWIEŃ KONSTYTUCJI RP}

Można stwierdzić, że ustawodawca traktuje problem ochrony środowiska w kategoriach zapewnienia bezpieczeństwa ekologicznego, o czym świadczy treść m.in. wspomnianego art. 5 Konstytucji RP, niemniej jednak nie jest to jedyny zapis konstytucyjny w przedmiotowym zakresie. W art. 31 Konstytucji RP ustawodawca sformułował bowiem rozwiązanie, które brzmi, że „ograniczenia w zakresie korzystania z konstytucyjnych wolności i praw mogą być ustanawiane tylko w ustawie i tylko wtedy, gdy są konieczne w demokratycznym państwie dla jego bezpieczeństwa lub porządku publicznego, bądź dla ochrony środowiska, zdrowia i moralności publicznej, albo wolności i praw innych osób. Ograniczenia te nie mogą naruszać istoty wolności i praw"12. Przywołany zapis dopuszcza zatem możliwość ograniczenia podstawowych konstytucyjnych praw, gdy sytuacja tego wymaga m.in. w celu ochrony środowiska, jakkolwiek wszelkie ograniczenia mają mieć charakter proporcjonalny, stosowny do zagrożeń. Niedopuszczalne będzie więc wprowadzenie takiego ograniczania - czy to przez jednorazową czy poszczególne regulacje w zakresie ochrony środowiska, aby nastąpiło naruszenie istoty praw i wolności ${ }^{13}$.

Kolejnym istotnym konstytucyjnym zapisem jest art. 68 ust. 4 Konstytucji RP, który wskazuje, że to władza publiczna ma obowiązek zwalczania chorób epidemicznych oraz zapobiegać negatywnym dla zdrowia skutkom degradacji środowiska. W prezentowanym zapisie jest mowa o potrzebie nie tylko ochrony zdrowia, ale także o prawie do życia w sprzyjającym środowisku, które wprost nie zostało wyrażone. Wskazana bowiem treść ukazuje jako dobro chronione ludzkie zdrowie, a nie środowisko jako dobro samo w sobie. Ustawodawca dostrzega jednak, iż niemożliwe jest prawidłowe i skuteczne chronienie zdrowia, jeśli działania w tym zakresie będą oderwane od ochrony środowiska ${ }^{14}$.

Z kolei w art. 74 Konstytucji RP wskazano, że władza publiczna prowadzi politykę zapewniającą bezpieczeństwo ekologiczne zarówno współczesnemu, jak również przyszłym pokoleniom ${ }^{15}$. Przedmiotem zatem zapewnienia bezpieczeństwa ekologicznego jest prowadzenie odpowiedniej polityki w tym zakresie, zaś zobowiązanie to jest adresowane do wszystkich organów i instytucji państwowych oraz samorządowych, a dotyczy wszel-

${ }^{11}$ E. Nowak, M. Nowak, Zarys teorii bezpieczeństwa narodowego, Warszawa, 2011, s. 127.

${ }^{12}$ Art. 31 ust 3 Konstytucji RP.

${ }^{13}$ B. Rakoczy, Komentarz do Konstytucji...

14 Ibidem.

15 Art. 74 ust. 1 Konstytucji RP. 
kiego rodzaju działań (tak władczych, jak i organizatorsko-inspiracyjnych), o ile ukierunkowane są politycznej koncepcji w tym obszarze ${ }^{16}$.

Organami administracji publicznej zobowiązanymi do ochrony środowiska naturalnego w Polsce są zatem: minister właściwy do spraw środowiska, generalny dyrektor ochrony środowiska, regionalni dyrektorzy ochrony środowiska, wojewodowie, marszałkowie województw, sejmiki wojewódzkie, starostowie, prezydenci miast, burmistrzowie oraz wójtowie $^{17}$.

Konstytucja RP nadaje również obywatelom prawo do żądania informacji o stanie $\mathrm{i}$ ochronie środowiska ${ }^{18}$. Wskazane uprawnienie szczegółowo reguluje ustawa z 3 października 2008 r. o udostępnianiu informacji o środowisku i jego ochronie, udziale społeczeństwa w ochronie środowiska oraz o ocenach oddziaływania na środowisko ${ }^{19}$.

Warto podkreślić, iż prawo do informacji o środowisku nie zależy od wykazania interesu prawnego w tym zakresie. Jest ono traktowane w sposób samoistny, a informacja o środowisku, o inwestycjach oddziałujących na środowisko oraz o zagrożeniach w tym zakresie służy najbardziej żywotnym interesom człowieka. Może ona bowiem wpłynąć na realizację innych wolności i praw konstytucyjnych, a zwłaszcza na wybór miejsca zamieszkania, wybór prowadzonej działalności gospodarczej, planowanie przedsięwzięć gospodarczych lub realizację innych planów w równie ważnych sferach życia jednostki dlatego też stanowi istotny element w życiu obywateli ${ }^{20}$.

Ponadto należy także zwrócić uwagę na art. 86 Konstytucji RP, który stanowi, że „każdy jest obowiązany do dbałości o stan środowiska i ponosi odpowiedzialność za spowodowane przez siebie jego pogorszenie zaś zasady tej odpowiedzialności określa ustawa", co znajduje rozwinięcie w różnych aktach normatywnych ${ }^{21}$.

Środowisko zatem, jak również jego ochrona, stanowią szczególny przedmiot troski ustawodawcy, czego wyrazem są chociażby stosowne regulacje ujęte w ustawie zasadniczej. Jest to wyraz konsekwencji w zakresie ochrony środowiska ${ }^{22}$.

\section{OCHRONA ŚRODOWISKA W ADMINISTRACJI OBRONY NARODOWEJ}

W myśl art. 5 pkt 14 w zw. z art. 19 ust. 1-2 ustawy z dnia 4 września 1997 r. o działach administracji rządowej ${ }^{23}$ dział obrona narodowa obejmuje, w czasie pokoju, sprawy: obrony państwa oraz Sił Zbrojnych RP, udziału RP w wojskowych przedsięwzięciach organizacji międzynarodowych oraz w zakresie wywiązywania się z zobowiązań militarnych, wynikających z umów międzynarodowych, jak również umów offsetowych - chyba

\footnotetext{
${ }^{16}$ L. Garlicki, M. Zubik (red.), Konstytucja Rzeczypospolitej Polskiej. Komentarz, t. II, wyd. II (lex online 12.07.2017 r.).

${ }_{17}$ S. Śladkowski, B. Bonisławska, Administracja publiczna i środowisko, Warszawa 2010, s. 21.

18 Art. 74 ust. 3 Konstytucji RP.

19 Tekst jedn. Dz.U. z 2017 r., poz. 1405.

${ }^{20}$ M. Haczkowska (red.), Konstytucja Rzeczypospolitej Polskiej. Komentarz (lex online 12.07. 2017 r.)

${ }^{21}$ Zob. np. zapobieganie zanieczyszczeniu morza przez statki - ustawa z dnia 16 marca $1995 \mathrm{r}$. (tekst jedn. Dz.U. z 2017 r., poz. 2000 ze zm.); ochrona zwierząt - ustawa z dnia 21 sierpnia 1997 r. (tekst jedn. Dz.U. z 2017 r., poz. 1840 ze zm.); utrzymanie czystości i porządku w gminach - ustawa z dnia 13 września 1996 r. (tekst jedn. Dz.U. z 2017 r., poz. 1289 ze zm.).

${ }^{22}$ B. Rakoczy, Komentarz do Konstytucji Rzeczypospolitej Polskiej...

${ }^{23}$ Dz.U. z 2017 r., poz. 888 ze zm.
} 
że na mocy odrębnych przepisów określone sprawy należą do zakresu zadań i kompetencji Prezydenta RP lub innych organów państwowych.

Natomiast zgodnie z art. 1 ust. 1 ustawy z dnia 14 grudnia 1995 r. o urzędzie Ministra Obrony Narodowej ${ }^{24}$ minister obrony narodowej kieruje działem - obrona narodowa oraz jest organem, za którego pośrednictwem prezydent RP sprawuje w czasie pokoju zwierzchnictwo nad Siłami Zbrojnymi $\mathrm{RP}^{25}$. Minister ten wykonuje swoje zadania przy pomocy Ministerstwa Obrony Narodowej, w skład którego wchodzi Sztab Generalny Wojska Polskiego ${ }^{26}$.

Do zakresu działania ministra obrony narodowej należy:

- kierowanie w czasie pokoju całokształtem działalności Sił Zbrojnych;

- przygotowywanie założeń obronnych państwa, w tym propozycji dotyczących rozwoju i struktury Sił Zbrojnych;

- formowanie, przeformowywanie i rozformowywanie jednostek wojskowych oraz nadawanie im etatów;

- realizowanie generalnych założeń, decyzji i wytycznych Rady Ministrów w zakresie obrony państwa i koordynowanie realizacji wynikających z nich zadań;

- sprawowanie, w zakresie powierzonym przez Radę Ministrów, ogólnego nadzoru nad realizacją zadań obronnych przez organy administracji rządowej, organy jednostek samorządu terytorialnego, instytucje państwowe, przedsiębiorców i inne podmioty;

- sprawowanie ogólnego kierownictwa w sprawach wykonywania powszechnego obowiązku obrony;

- kierowanie administracją rezerw osobowych dla celów powszechnego obowiązku obrony;

- ogólna koordynacja działań w zakresie ochrony informacji niejawnych w dziale obrony narodowej;

- określanie celów, kierunków i zadań szkolnictwa wojskowego;

- kierowanie sprawami kadrowymi Sił Zbrojnych;

- kierowanie wykonywaniem obowiązku służby wojskowej, wychowywaniem żołnierzy oraz sprawami zaspokajania ich potrzeb socjalno-bytowych;

- kierowanie sprawami zaspokajania potrzeb materiałowych, technicznych i finansowych Sił Zbrojnych;

- kierowanie sprawami pracowniczymi w resorcie obrony narodowej;

- realizowanie decyzji Rady Ministrów w zakresie udziału RP w wojskowych przedsięwzięciach organizacji międzynarodowych oraz w zakresie wywiązywania się z zobowiązań militarnych, wynikających z umów międzynarodowych;

- zawieranie umów międzynarodowych wynikających z decyzji Rady Ministrów, dotyczących udziału polskich kontyngentów wojskowych w międzynarodowych misjach pokojowych i akcjach humanitarnych oraz ćwiczeń wojskowych prowadzonych wspólnie z innymi państwami lub organizacjami międzynarodowymi;

- tworzenie, ustalanie organizacji i kierowanie działalnością przedstawicielstw wojskowych za granicą;

\footnotetext{
${ }^{24}$ Tekst jedn. Dz.U. z 2017 r., poz. 2149 ze. zm. (dalej jako: uMON).

25 Art. 132 ust. 2 Konstytucji RP.

26 Art. 1 ust. 2 uMON.
} 
- utrzymywanie kontaktów z resortami obrony innych państw oraz z wojskowymi organizacjami międzynarodowymi;

- realizowanie celów oraz zobowiązań sojuszniczych wynikających z udziału Rzeczypospolitej Polskiej w Programie Inwestycji Organizacji Traktatu Północnoatlantyckiego w Dziedzinie Bezpieczeństwa (NSIP);

- kierowanie gospodarką finansową resortu obrony narodowej;

- reprezentowanie Skarbu Państwa w stosunku do mienia znajdującego się w posiadaniu jednostek organizacyjnych resortu obrony narodowej, a także wykonywanie określonych w ustawach czynności w stosunku do państwowych jednostek budżetowych i form gospodarki pozabudżetowej, działających w resorcie obrony narodowej;

- kierowanie działalnością gospodarczą w Siłach Zbrojnych;

- wykonywanie czynności określonych w ustawach w stosunku do szkół wojskowych, wojskowych jednostek badawczo-rozwojowych, przedsiębiorstw państwowych, dla których jest organem założycielskim, wojskowych zakładów opieki zdrowotnej, agencji i fundacji;

- kierowanie terenowymi organami wykonawczymi w sprawach operacyjno-obronnych i rządowej administracji niezespolonej;

- współdziałanie $\mathrm{z}$ innymi organami państwowymi, organami samorządu terytorialnego i organizacjami społecznymi;

- zawieranie i obsługa umów offsetowych;

- wykonywanie innych zadań wynikających z ustaw i innych przepisów ${ }^{27}$.

Mówiąc zaś o obowiązkach administracji obrony narodowej w sferze ochrony środowiska wynikających z przepisów powszechnie obowiązujących należy wyraźnie podkreślić na treść rozporządzenia Ministra Obrony Narodowej z dnia 24 marca 2016 r. w sprawie przestrzegania przepisów o ochronie środowiska w komórkach i jednostkach organizacyjnych podległych Ministrowi Obrony Narodowej albo przez niego nadzorowanych ${ }^{28}$. Ten bowiem akt wykonawczy określa organy odpowiadające za nadzór nad przestrzeganiem przepisów o ochronie środowiska w komórkach i jednostkach organizacyjnych podległych ministrowi obrony narodowej albo przez niego nadzorowanych, jak też zakres odpowiedzialności i kompetencje przysługujące ww. komórkom i jednostkom organizacyjnym.

Najszerszy zatem katalog obowiązków w omawianym zakresie powierzony został Dowódcy Operacyjnemu Rodzajów Sił Zbrojnych oraz Dowódcy Garnizonu Warszawa, którzy to m.in.:

- nadzorują stosowanie przepisów o ochronie środowiska w podległych im jednostkach organizacyjnych, w szczególności: w działalności szkoleniowej, przy zabezpieczeniu logistycznym działań, w tym działań na polskich obszarach morskich, a także na morzach i w portach innych państw w czasie prowadzenia ćwiczeń i szkoleń lub odbywania wizyt poza polskimi obszarami morskimi, jak również podczas wspólnych operacji i ćwiczeń w ramach członkostwa w Organizacji Traktatu Północnoatlantyckiego, UE lub Partnerstwa dla Pokoju, z uwzględnieniem postanowień umów i porozumień międzynarodowych;

\footnotetext{
27 Art. 2 uMON.

${ }^{28}$ Dz.U. z 2016 r., poz. 473 (dalej jako: rozporządzenie MON).
} 
- uwzględniają problematykę ochrony środowiska w procesie kształcenia i szkolenia w podległych im jednostkach;

- organizują przedsięwzięcia z zakresu ochrony środowiska w podległych im jednostkach organizacyjnych $w$ miarę potrzeb wynikających $\mathrm{z}$ ich działalności oraz występują do właściwych organów planujących o przydział środków finansowych na ten cel;

- koordynują w podległych im jednostkach organizacyjnych powoływanie osób odpowiedzialnych za realizację zadań z zakresu ochrony środowiska w ramach posiadanych limitów stanowisk etatowych;

- w terminie do dnia 15 kwietnia za rok poprzedni, na podstawie informacji o stanie środowiska i działalności proekologicznej przekazywanych przez podległe im jednostki organizacyjne, opracowują i przedstawiają Szefowi Inspektoratu Wsparcia Sił Zbrojnych informację o stanie środowiska i działalności proekologicznej na terenach tych jednostek;

- uczestniczą w procesie ratyfikacji i implementacji dokumentów standaryzacyjnych Organizacji Traktatu Północnoatlantyckiego w zakresie ochrony środowiska;

- uczestniczą w opracowaniu planów ochrony środowiska poligonu wojskowego;

- zapewniają udział swoich przedstawicieli w specjalistycznych szkoleniach z zakresu ochrony środowiska organizowanych przez dyrektora komórki organizacyjnej Ministerstwa Obrony Narodowej właściwej do spraw infrastruktury oraz Szefa Inspektoratu Wsparcia Sił Zbrojnych;

- biorą udział, zgodnie z właściwościami, w pracach nad sporządzaniem planu zadań ochronnych i planu ochrony dla obszarów obejmujących tereny wykorzystywane przez Siły Zbrojne RP w obrębie siedlisk przyrodniczych i siedlisk gatunków, dla których wyznaczono obszar Natura $2000^{29}$.

Ponadto, w przywołanym rozporządzeniu $\mathrm{w}$ sprawie przestrzegania przepisów o ochronie środowiska w komórkach i jednostkach organizacyjnych podległych MON albo przez niego nadzorowanych - dyrektor jednostki organizacyjnej w resorcie obrony narodowej właściwej do spraw działalności metrologicznej oraz Prezes Agencji Mienia Wojskowego:

- odpowiadają za przestrzeganie przepisów o ochronie środowiska oraz nadzorują i organizują realizację przedsięwzięć z tego zakresu w jednostce organizacyjnej, którą kierują, oraz w jednostkach im podległych, jak również na terenach będących $\mathrm{w}$ ich użytkowaniu, $\mathrm{w}$ tym przedsięwzięć związanych $\mathrm{z}$ przywracaniem do właściwego stanu elementów środowiska zanieczyszczonych, uszkodzonych lub zniszczonych na obszarze swojego działania;

- monitorują przekazywanie przez podległe im jednostki organizacyjne informacji o wykorzystywanych niebezpiecznych substancjach chemicznych według stanu na dzień 31 grudnia za rok poprzedni;

- prowadzą ewidencje substancji zubożających warstwę ozonową oraz niektórych fluorowanych gazów cieplarnianych;

- w terminie do dnia 15 kwietnia za rok poprzedni, na podstawie informacji o stanie środowiska i działalności proekologicznej przekazywanych przez podległe im jednostki organizacyjne, opracowują i przedstawiają Szefowi Inspektoratu

\footnotetext{
$29 \S 3$ rozporządzenia MON.
} 
Wsparcia Sił Zbrojnych informację o stanie środowiska i działalności proekologicznej na swoim terenie i na terenach tych jednostek ${ }^{30}$.

Warto również dodać, iż kolejną kategorią odbiorców danego rozporządzenia są rektorzy-komendanci uczelni wojskowych, na których spoczywa:

- odpowiedzialność za przestrzeganie przepisów o ochronie środowiska i organizacja przedsięwzięcia $\mathrm{z}$ tego zakresu w jednostce, którą kierują, w tym przedsięwzięcia związane z przywracaniem do właściwego stanu elementów środowiska zanieczyszczonych, uszkodzonych lub zniszczonych w nieruchomościach będących własnością uczelni lub na terenach przez nią użytkowanych, jeżeli umowa użytkowania tak stanowi;

- obowiązek prowadzenia ewidencji niebezpiecznych substancji chemicznych wykorzystywanych przez jednostkę, którą kierują, według stanu na dzień 31 grudnia roku poprzedniego;

- obowiązek prowadzenia ewidencji substancji zubożających warstwę ozonową oraz niektórych fluorowanych gazów cieplarnianych;

- obowiązek prowadzenia ewidencji zawierających informacje i dane o zakresie korzystania ze środowiska, w szczególności ewidencję zawierającą dane potrzebne do naliczania opłat za korzystanie ze środowiska;

- obowiązek opracowania i przedstawienia - w terminie do dnia 15 kwietnia za rok poprzedni - Szefowi Inspektoratu Wsparcia Sił Zbrojnych informacji o stanie środowiska i działalności proekologicznej w nieruchomościach będących własnością jednostki, którą kierują, lub przez nią użytkowanych, jeżeli na podstawie umowy użyczenia jednostka, którą kierują, była do takich działań zobowiązana;

- obowiązek przesyłania przekazywanych poza jednostkę, którą kierują, ewidencji oraz informacji do wiadomości dyrektorowi komórki organizacyjnej Ministerstwa Obrony Narodowej właściwej do spraw nauki i szkolnictwa wojskowego w terminie właściwym do ich przekazania adresatowi ${ }^{31}$.

Do podmiotów, którym nadano wskazane obowiązki należą m.in.: Szef Inspektoratu Wsparcia Sił Zbrojnych, Szef Wojskowej Ochrony Przeciwpożarowej, Szef Wojskowego Dozoru Technicznego, Szef Wojskowej Inspekcji Gospodarki Energetycznej, kierownicy jednostek organizacyjnych podległych Ministrowi Obrony Narodowej albo przez niego nadzorowanych władający nieruchomościami wojskowymi w formie trwałego zarządu lub na podstawie innego tytułu prawnego, jak również dyrektorzy komórek organizacyjnych obsługujących Ministerstwo Obrony Narodowej w zakresie zarządzania i administrowania nieruchomościami pozostającymi w trwałym zarządzie Ministerstwa Obrony Narodowej, wykonujący funkcję zarządców.

\section{PODSUMOWANIE}

Potrzeba egzystowania w zdrowym i atrakcyjnym środowisku naturalnym wymusza podjęcie odpowiednich działań zmierzających do eliminacji lub zminimalizowania źródeł zagrożeń dla tej sfery. Podstawowe zaś obowiązki w zakresie ochrony środowiska, czy też szerzej ujmując, w obszarze zapewnienia bezpieczeństwa ekologicznego w państwie zostały określone w ustawie zasadniczej. Takie natomiast rozwiązanie oznacza potrzebę

\footnotetext{
$30 \S 5$ rozporządzenia MON.

31 § 6 rozporządzenia MON.
} 
zaangażowania całego aparatu administracyjnego w celu skutecznego zapewnienia wymaganego poziomu środowiska naturalnego. W rozwiązywanie zatem dylematów związanych z ochroną środowiska musi być zaangażowany cały system organów publicznych. Poza tym obowiązek ochrony środowiska obejmując wiele aspektów aktywności władz publicznych, pozwala wyodrębnić i wskazać na stosowne powinności w tym zakresie $\mathrm{w}$ jednym $\mathrm{z}$ istotnych działów administracji rządowej, czyli w resorcie obrony narodowej. I choć artykuł zwraca jedynie uwagę na fragmentaryczne rozwiązania normatywne określonych przez ministra obrony narodowej $\mathrm{w}$ jednym $\mathrm{z}$ wydanych przez ten organ aktów wykonawczych, które obowiązują w omawianym zakresie, tym niemniej rozwiązania te, pomimo swojego incydentalnego charakteru dowodzą, iż specyfika administracji obrony narodowej, szczególnie na skutek zróżnicowanego zakresu działania MON również uwzględnia wymóg zachowania należytego poziomu ochrony środowiska.

\section{LITERATURA}

[1] Garlicki L., Zubik M. (red.), Konstytucja Rzeczypospolitej Polskiej. Komentarz, t. II, wyd II, lex online.

[2] Haczkowska M. (red.), Konstytucja Rzeczypospolitej Polskiej. Komentarz, lex online.

[3] Jurgilewicz M., Bezpieczeństwo zgromadzeń. Komentarz praktyczny, Warszawa 2015.

[4] Kaczmarek J., Łepkowski W., Zdrodowski B. (red.), Stownik terminów z zakresu bezpieczeństwa narodowego, Warszawa 2008.

[5] Nowak E., Nowak M., Zarys teorii bezpieczeństwa narodowego, Warszawa 2011.

[6] Rakoczy B., Komentarz do Konstytucji Rzeczypospolitej Polskiej [w:] Prawo ochrony środowiska. Komentarz, lex online.

[7] Skrzydło W., Konstytucja Rzeczypospolitej Polskiej, Komentarz, Wydanie VII, lex online.

[8] Stańczyk J., Wspótczesne pojmowanie bezpieczeństwa, Warszawa 1996.

[9] Śladkowski S., Bonisławska B., Administracja publiczna i środowisko, Warszawa 2010.

\section{AKTY PRAWNE}

[1] Konstytucja Rzeczypospolitej Polskiej z dnia 2 kwietnia 1997 r. (Dz.U. z 1997 r., nr 78, poz. 483 ze zm.).

[2] Ustawa z dnia 14 grudnia 1995 r. o urzędzie Ministra Obrony Narodowej (tekst jedn. Dz.U. z 2017 r., poz. 2149 ze zm.).

[3] Ustawa z dnia 4 września 1997 r. o działach administracji rządowej (tekst jedn. Dz.U. z 2017 r., poz. 888 ze zm.).

[4] Ustawa z 3 października 2008 r. o udostępnianiu informacji o środowisku i jego ochronie, udziale społeczeństwa w ochronie środowiska oraz o ocenach oddziaływania na środowisko (tekst jedn. Dz.U. z 2017 r., poz. 1405 ze zm.).

[5] Rozporządzenie Ministra Obrony Narodowej z dnia 24 marca 2016 r. w sprawie przestrzegania przepisów o ochronie środowiska w komórkach i jednostkach organizacyjnych podległych Ministrowi Obrony Narodowej albo przez niego nadzorowanych (Dz.U. z 2016 r., poz. 473). 


\section{RESPONSIBILITIES OF THE NATIONAL DEFENSE ADMINISTRATION IN THE FIELD OF ENVIRONMENTAL PROTECTION}

The natural environment is a universal value. Every unit in the state has the right to freely use the natural environment, but in order to preserve its desired condition there are certain limitations related to its use and the obligations that society must perform in order to maintain it in a proper state. In fact, environmental protection boils down to taking actions or omissions that make it possible to preserve or restore the natural balance. The point here is to shape the environment in a rational way, as well as manage its resources in accordance with the principle of sustainable development, counteracting pollution, or restoring natural elements to the state of ownership. Environmental protection is, therefore, one of the main tasks of the state, so due to the progress of civilization, more and more activities in this area are attributed to various public administration entities, including a certain sphere of tasks in this area was entrusted to the department of government administration - national defense. Public administration has been equipped with numerous legal instruments and tools that enable it to protect the natural environment from factors that could adversely affect its degradation. On the other hand, universal normative regulations in this area are an example of desirable solutions aimed at preventing threats to the natural environment. The presented article is, therefore, aimed at showing the environmental protection issues in the aspect of the duties that the administration of national defense has to fulfill in this respect.

Keywords: safety, environment, administration, national defense.

DOI: $10.7862 / \mathrm{rz} .2017 . \mathrm{mmr} .26$

Tekst złożono w redakcji: grudzień $2017 \mathrm{r}$.

Przyjęto do druku: grudzień 2017 r. 
